\title{
Perceptions of Entrepreneurship as a Career Option in South Africa: An Exploratory Study among Grade 12 Learners
}

\author{
L Burger \\ Graduate School of Business, University of Stellenbosch \\ D Mahadea and C O' Neill \\ School of Business, University of KwaZulu-Natal
}

\begin{abstract}
Job creation and poverty alleviation are two pressing challenges facing South Africa today. South Africa's capacity to address the high unemployment and poverty levels are partly hampered by a poorly developed entrepreneurial culture. An entrepreneurial culture that enhances the supply of effective entrepreneurs at all age and population groups could contribute to economic growth and address both unemployment and poverty. This article investigates the perceptions of entrepreneurship as career option by Grade 12 learners in a specific region in South Africa, as the youth could be viewed as the logical group from which new entrepreneurs should emerge in future. The majority of the surveyed learners seem to have a positive disposition towards small business entrepreneurship as an eventual career, although considerable differences exist in terms of self-image, locality and ethnic backgrounds.
\end{abstract}

JEL J23, 24, M13

\section{INTRODUCTION}

Despite all efforts from government, business and non-profit organisations to combat poverty, between 40 per cent and 50 per cent of the population in South Africa still has incomes below poverty levels (May, Woolard \& Klasen, 2000: 48). Certain population groups are more vulnerable than others to the poverty situation: in 1998 the poverty rate (below R353 per month) was 70,9 per cent in the rural areas, 60 per cent in households headed by females and 60,7 per cent in black communities (Development Bank of Southern Africa, DBSA, 1998: 1719). Breaking the cycle of poverty is proving to be a very demanding challenge. May, Woolard and Klasen (2000: 48) argue that: “... the specific history of South Africa appears to have set in motion forces that potentially trap individuals, households and groups in poverty. These forces include skewed 
access to resources, institutional failures and the operation of markets". The important question is how to break this apparent cycle of impoverishment against a backdrop of positive economic growth rates and rising rates of unemployment in post-apartheid South Africa.

The public and private sectors have, in recent times, been shedding labour in response to economic imperatives of the domestic and global circumstances. As the number of people without employment rises, more and more individuals especially those with previous working experience might take the route to entrepreneurship of starting up small or micro ventures. The school leavers and new entrants to the job market need to be aware of the realities of the changing market conditions in South Africa and they should consider enhancing their employability prospects by taking the entrepreneurial path to be job-creators rather than job-seekers. Evidently they need to have the right entrepreneurial attitudes. Against this background, this paper examines the entrepreneurial attitudes of grade 12 learners from a set of secondary schools in the Stellenbosch area of the Western Cape Province. The paper consists of four sections. The first presents elements of the current entrepreneurial and labour market conditions in South Africa. The second examines the research design. The third covers the findings and the last section presents a discussion of the results with some concluding remarks.

\section{ENTREPRENEURSHIP AND LABOUR MARKET CONDITIONS IN SOUTH AFRICA}

In South Africa only 22 per cent of the individuals between 16-64 years who were living in poor households were employed, compared to 60 per cent of the corresponding group in households with incomes above the poverty line (May et al., 2000: 38). According to Carol O'Brien, policy executive of the South African Chamber of Commerce, total employment in 2002 was 10 per cent lower than in 1970 (Ferris, 2003: 6), and it decreased further by 106000 in the first half of 2003 (SARB, March 2004: 12). Statistics South Africa reported that the official unemployment rate for South Africa in 2001 was 26,4 per cent and 37 per cent according to the expanded definition of unemployment (Lehohla, 2002: 94). In rural areas the respective figures were 33,9 per cent and 52,2 per cent (Lehohla, 2002: 94).

Not only does South Africa have a high poverty and unemployment rate, the country has, after Brazil, the most skewed income distribution in the world. With a per capita GDP of R13 773 the income share of the poorest 40 per cent of the households was 11 per cent of the GDP, while the richest 10 per cent earned 40 per cent of the income (DBSA, 1998: 17-19). This suggests that a 
large portion of the people in South Africa cannot benefit significantly unless the country registers rapid economic growth underpinned by massive job creation and income as well as productivity gains, particularly among the poorer segments of the society. Entrepreneurship, as defined by the application of individuals' creative talents and their harnessing of the necessary resources to exploit market gap opportunities by venturing into value-adding business activities, has the potential to contribute towards a country's economic growth. It is one of the factors contributing towards long-term economic empowerment, where particularly disadvantaged people can improve their financial situation, through starting and expanding small businesses. Admittedly, there are different degrees of entrepreneurship, each associated with certain risk-return pay off conditioned on the risk propensities and alertness of individuals (Kaplan, 2003: 5; Burch, 1986: 4).

In 2001, 2002 and 2003 South Africa was included in an international Global Entrepreneurship Monitor (GEM) research project which included respectively 29, 37 and 31 participating countries. The GEM, launched in 1997, provides a forum for public policy debates on entrepreneurship, specially analysing how entrepreneurial activity impacts on a country's economic growth and what factors affect the level of entrpreneurship (Kaplan, 2003). In 2002 South Africa ranked $19^{\text {th }}$ out of 37 - an average rate of entrepreneurial activities when compared to other countries (Foxcroft, Wood, Kew, Herrington \& Segal, 2002: 4). South Africa's relative position worsened, in terms of total entrepreneurial activity index, over the past couple of years, standing at $14^{\text {th }}$ and $22^{\text {nd }}$ in 2001 and 2003 respectively (Orford, Wood, Fischer, Herrington \& Segal, 2003: 3). There were indications that the survival rate of local start-ups was low and that opportunity entrepreneurial activities were the lowest of all participating developing countries (Orford et al., 2003; Foxcroft et al., 2002: 4, 59).

The perceived availability of business opportunities and business skill levels of the business people studied in the 2001 and 2003 GEM reports were well below the international mean (Driver et al., 2001: 3). The reports highlighted that entrepreneurship was not well-supported in the South African community and that business failure was perceived negatively and carried a social stigma. If the penalty of failure is high, it would surely inhibit many people from taking calculated risks in businesses. The reports also noted low levels of trust in business and personal relations, difficulties in accessing finance, a partial failure of education and training to sufficiently develop entrepreneurial skills at secondary and post-secondary levels, gender discrimination to funding and certain cultural practices as limiting factors to entrepreneurship. Additionally, there were other constraints such as a lack of initiative, confidence and creativity in certain critical business areas in South Africa (Orford et al., 2003: 12; Driver et al., 2001: 4). 
The level of entrepreneurial activity in a country has an impact on its economic growth and development (Foxcroft et al., 2002: 20). Entrepreneurial firms in South Africa are responsible for one third of the country's total employment this figure excluded the owners' employment (Foxcroft et al., 2002: 19). Reynolds, Hay and Camp (1999: 13-16) observed that up to one-third of the variation in economic growth in the ten countries they studied could be attributed to the variation in rates of entrepreneurship.

South Africa has a problem common with many other developing countries in that a growing number of people start businesses not because they have found an appropriate niche in the market, but because of necessity. Orford et al. (2003: 10) and Driver et al. (2001: 11) referred to this as necessity entrepreneurship and contrasted it to opportunity entrepreneurship, where people start business ventures to react to opportunities which they have perceived in the market. Often these necessity entrepreneurs do not have the necessary business experience, skills and resources to equip them for such a venture and they end up with an income that is below the poverty level, as is the case with at least 45 per cent of self-employed people in South Africa (Bhorat \& Leibbrandt, 1998: 28). Race, gender and location may be associated with poverty even among self-employed. Experienced self-employed persons with secondary education are more likely to have earnings above the poverty lines than their less educated or experienced counterparts (Bhorat \& Leibbrandt, 1998: 40).

GEM reports 2002 and 2003 showed a significant relationship between the level of education of business people and the survival rate of their businesses (Orford et al., 2003: 1; Foxcroft et al., 2002: 22). The level of education of the entrepreneurs and their need achievement tendencies also seem to have an impact on the number of jobs they create (Foxcroft et al., 2002: 22, Mahadea, 1994: 91). A worrying concern is that despite all policy initiatives, South Africa has displayed significantly lower levels of entrepreneurial activity, specifically about 50 per cent less than the average for GEM participating countries in the past two years. South Africa's ranking in the start-up rate dropped from $15^{\text {th }}$ in 2002 to $24^{\text {th }}$ in 2003 , and its new firm activity rate similarly registered a drop from $29^{\text {th }}$ (out of 37 countries) to $23^{\text {rd }}$ (out of 31 ) in the same period (Orford et al., 2003: 8).

If South Africa wants a healthy growing economy with a lower unemployment rate and a reduction in its poverty level, the country's entrepreneurial situation needs to improve significantly. South Africa needs a flourishing entrepreneurship (Mahadea, 2003: 22). It is critical to start with the young, especially educated, people as they are the country's future wealth producers and entrepreneurs. The question is: how do young people perceive small 
business and what are their prospects of becoming self-employed business persons? Do the perceptions of young people who are part of groups that are under-represented in the business world and those of their peers differ? Are there any indications that changes have already taken place in the perceptions of these young people? It may thus be very important to monitor the entrepreneurial capacity of South Africa's youth to determine whether any changes could be expected from the new generation of business leaders.

\section{RESEARCH DESIGN}

In the light of the shortage of skilled entrepreneurs experienced in South Africa, this survey aimed to supply additional information about the youth, the logical group from which emerging entrepreneurs could be expected. This study focused on grade 12 learners within a specific geographical area. According to literature the level of education is an important determinant of entrepreneurial capacity. In the research design this important variable (level of education) was controlled (although the quality of education which respondents received may still have varied). The survey investigated the learners' perceptions regarding entrepreneurial social norms (in terms of the occupational status of managers relative to entrepreneurs), their own views regarding business and becoming entrepreneurs, their future plans, reported self-image as well as demographic information. The research, per definition, does not distinguish between attitudes towards necessity and opportunity entrepreneurship.

Relevant data was gathered by means of interviews, aided with structured questionnaires.

A non-parametric approach was used for data analyses. The categories that were included were age, location, perceptions, gender, schools, ethnic group and mother tongue.

Three hundred and seventy learners from 8 schools in the Stellenbosch area were included in this survey, which represented a response rate of 68,6 per cent of the random sample. The research group does not represent the youth of South Africa in any way. Two schools that accommodate learners from farming areas, and are located in a rural area, were identified and categorised "rural", while the others (all in towns) were categorised "non-rural". In this way some attention could be paid to rural aspects in the relevant wider community and more distant communities with higher levels of deprivation of opportunities could also be identified. 
Ninety-one percent of the participants in the survey were between 17 and 19 years old, the genders were almost equally represented (female 53 per cent; male 47 per cent) and the distribution regarding first language was Afrikaans 70,0 per cent; English 13,5 per cent; Xhosa 13,5 per cent and other 2.5 per cent. Population group preference was: Coloured 44,9 per cent; White 40,3 per cent; Black 13,2 per cent and no response 1,4 per cent. The respondents were categorised as rural (24,9 per cent) and non-rural (75,1 per cent).

\section{RESULTS}

\subsection{Social perceptions regarding entrepreneurship}

Society's perception of entrepreneurship plays an important role in influencing the young individuals to choose between self- employment in a business and wage employment in the corporate sector, as a career. Respondents had to indicate whether people who run their own businesses were held in higher regard than managers in large private firms. Their responses were initially examined in terms of their geographical location.

Table 1.1 Respondents' perceptions of status of entrepreneurs relative to managers according to locality

\begin{tabular}{|l|c|c|c|c|c|c|c||}
\hline Locality & $\begin{array}{c}\mathbf{0 =} \\
\text { Strongly } \\
\text { disagree }\end{array}$ & $\begin{array}{c}\mathbf{1 =} \\
\text { Disagree }\end{array}$ & $\begin{array}{c}\mathbf{2 =} \\
\text { Not sure }\end{array}$ & $\begin{array}{c}\mathbf{3 =} \\
\text { Agree }\end{array}$ & $\begin{array}{c}\mathbf{4 =} \\
\text { Strongly } \\
\text { agree }\end{array}$ & Total & $\begin{array}{c}\text { Mean of } \\
\text { opinions }\end{array}$ \\
\hline $\begin{array}{l}\text { Non- } \\
\text { rural }\end{array}$ & 26 & 51 & 44 & 46 & 24 & 191 & 1,95 \\
$13,6 \%$ & $26,7 \%$ & $23.0 \%$ & $24,1 \%$ & $12,6 \%$ & $100,0 \%$ & \\
\hline Rural & 19 & 38 & 32 & 59 & 14 & 162 & 2,07 \\
& $11,7 \%$ & $23,5 \%$ & $19,8 \%$ & $36,4 \%$ & $8,6 \%$ & $100,0 \%$ & \\
\hline Total & 45 & 89 & 76 & 105 & 38 & 353 & 2,01 \\
& $12,75 \%$ & $25,2 \%$ & $21,5 \%$ & $29,8 \%$ & $10,8 \%$ & $100,0 \%$ & \\
\hline
\end{tabular}

Table 1.1 indicates that 38 per cent of the learners believed that managers of large firms were viewed more favourably by the community (strongly disagree or disagree), 40,6 per cent believed that entrepreneurs have the better image (agree or strongly agree), while 21,5 per cent could not choose between the two options (not sure). Overall, the learners from a rural background tend to have a stronger belief (mean=2.07) than their urban counterparts that entrepreneurs have a better positive image than managers. However, statistically location does not seem to significantly influence the youth perception regarding entrepreneurship $\left(x^{2}=6.78 ; d . f=4 ; p=0.14\right)$. 
The results are somewhat similar to those of Harrison, Hart and Donnelly (1989:15), who reported that their high school respondents in Northern Ireland also had a split opinion of 35,2 per cent agreeing that people had a higher regard for business owners and 38,6 per cent disagreeing. It was argued that managers in large firms there were already regarded by young people as having the 'ideal' job and if entrepreneurship compared so favourably to that option, then business entrepreneurship must be an attractive occupational path to be highly regarded by many individuals.

Figure 1 Respondents' perceptions regarding entrepreneurs relative to managers according to population group

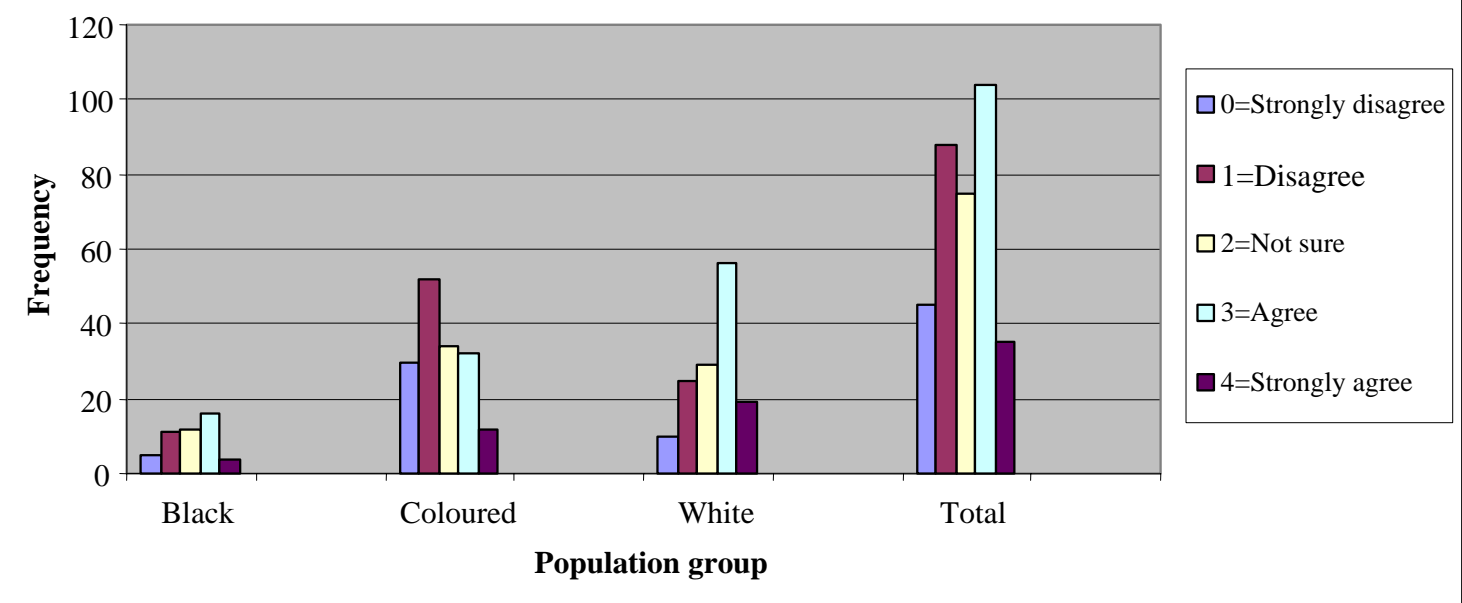

Peoples' perceptions regarding entrepreneurship may differ according to different population groups to which they belong to. Historically, during the apartheid years, Blacks were deprived of business opportunities. Black people, including females, are thus under-represented in the world of business in South Africa. The different population groups showed differences in their views regarding the public image of entrepreneurship relative to managers (Figure 1). The chi-square test showed that the hypothesis regarding no relationship between the perceptions on entrepreneurship and population groups could be rejected with a confidence level of more than 99 per cent. The perception regarding social norms differed according to population group (Figure 1), and respondents from the coloured population group reported the most negative $(n=52)$ and white learners had the most positive responses $(n=56)$. There was no evidence of a significant relationship between the gender of respondents and their reported perceptions of entrepreneurs' social status. 
The overall results tend to indicate positive social perceptions regarding entrepreneurship. The perceptions of the rural group and White group were significantly more positive than the alternative group.

\subsection{Respondents' own perceptions regarding entrepreneurship}

The next question to be analysed was a more personal one about the respondents" own career preferences regarding entrepreneurship: "Working for a large firm will offer me a better future career than running my own business". The responses are summarised in Tables 1.2 and 1.3 and presented with a breakdown according to population groups and locality.

Almost 44 per cent (149) of the respondents disagreed/strongly disagreed that a large firm would offer a better career option, 21,8 per cent was unsure and 34,5 per cent agreed (91) or strongly agreed (27).

Table 1.2 Respondents' perceptions regarding entrepreneurship according to population group

\begin{tabular}{|l|c|c|c|c|c|c|c|}
\hline Gender & $\begin{array}{c}\mathbf{0 =} \\
\text { Strongly } \\
\text { disagree }\end{array}$ & $\begin{array}{c}\mathbf{1}= \\
\text { Disagree }\end{array}$ & $\begin{array}{c}\mathbf{2 =} \\
\text { Not sure }\end{array}$ & $\begin{array}{c}\mathbf{3}= \\
\text { Agree }\end{array}$ & $\begin{array}{c}\mathbf{4}= \\
\text { Strongly } \\
\text { agree }\end{array}$ & Total & $\begin{array}{c}\text { Mean of } \\
\text { opinions }\end{array}$ \\
\hline Black & 16 & 11 & 4 & 13 & 5 & 49 & 1,59 \\
& $30,8 \%$ & $11,3 \%$ & $5,3 \%$ & $14,3 \%$ & $18,5 \%$ & $14,3 \%$ & \\
\hline Coloured & 28 & 49 & 34 & 32 & 11 & 154 & 1,67 \\
& $53,9 \%$ & $50,5 \%$ & $45,3 \%$ & $35,2 \%$ & $40,7 \%$ & $45,0 \%$ & \\
\hline White & 8 & 37 & 37 & 46 & 11 & 139 & 2,11 \\
& $15,4 \%$ & $38,1 \%$ & $49,3 \%$ & $50,6 \%$ & $40,7 \%$ & $40,6 \%$ & \\
\hline Total & 52 & 97 & 75 & 91 & 27 & 342 & 1,84 \\
& $100,0 \%$ & $100,0 \%$ & $100,0 \%$ & $100,0 \%$ & $100,0 \%$ & $100,0 \%$ & \\
\hline
\end{tabular}

This suggests that almost 44 per cent of these respondents chose entrepreneurship as the better option than working in the corporate sector. When the responses are analysed according to population groups, Whites had the most positive perceptions (mean score $=2.11$ ). Black people had a lower score (1.59) regarding perceptions than coloured people. However, in Table 1.1 it was the other way around inferring that proportionately Blacks seem to be more averse to risk-taking associated with entrepreneurship than Whites or coloured persons.

Table 1.3 presents the respondents' perceptions according to locality (rural or non-rural area). The respondents from rural areas had on average (mean score $=1.47$ ) more negative views regarding entrepreneurship as a personal career 
choice than those from urban areas. Additionally, the chi-square test reflects that the locality of the young surveyed learners seem to significantly influence their perceptions about entrepreneurship $\left(\mathrm{x}^{2}=12.47\right.$; $\left.\mathrm{d} . \mathrm{f}=4 ; \mathrm{p}=0.01\right)$. White respondents from non-rural areas had exactly the same mean score for social norm perceptions and personal perceptions regarding entrepreneurship (tables 1.1 and 1.3); respondents from rural groups were in comparison more positive regarding the broader issue, but less positive when it became a personal matter.

$\begin{array}{llr}\text { Table 1.3 Respondents' perceptions } & \text { regarding entrepreneurship } \\ \text { according to locality }\end{array}$

\begin{tabular}{|l|c|c|c|c|c|c|c|}
\hline Locality & $\begin{array}{c}\mathbf{0 =} \\
\text { Strongly } \\
\text { disagree }\end{array}$ & $\begin{array}{c}\mathbf{1}= \\
\text { Disagree }\end{array}$ & $\begin{array}{c}\mathbf{2 =} \\
\text { Not sure }\end{array}$ & $\begin{array}{c}\mathbf{3 =} \\
\text { Agree }\end{array}$ & $\begin{array}{c}\mathbf{4}= \\
\text { Strongly } \\
\text { agree }\end{array}$ & Total & $\begin{array}{c}\text { Mean of } \\
\text { opinions }\end{array}$ \\
\hline $\begin{array}{l}\text { Non- } \\
\text { rural }\end{array}$ & $\begin{array}{c}37 \\
68,5 \%\end{array}$ & $67,4 \%$ & 59 & 80 & 23 & 265 & 1,95 \\
\hline Rural & 17 & 32 & 17 & 12 & 5 & 83 & 1,47 \\
& $31,5 \%$ & $32,7 \%$ & $22,4 \%$ & $13,0 \%$ & $17,9 \%$ & $23,9 \%$ & \\
\hline Total & 54 & 98 & 76 & 92 & 28 & 348 & 1,83 \\
& $100,0 \%$ & $100,0 \%$ & $100,0 \%$ & $100,0 \%$ & $100,0 \%$ & $100,0 \%$ & \\
\hline
\end{tabular}

The different responses of the two subgroups to the two sets of questions appear intriguing. Two possible factors might explain this. One is the acquiescence response discussed in the literature (Campbell \& Russo, 2001: 154), namely the tendency among certain respondents to be more inclined to agree with a statement than to disagree. The second is a cultural factor. The fact is that only certain subgroups (namely the rural group and Black respondents) showed these differences in results and if they were due to the acquiescence response the question would still be why these respondents had a stronger need to give positive responses or were more eager to make a good impression. This clearly indicates that the two groups of respondents' personal and cultural perceptions regarding entrepreneurship may be incongruent. These two subgroups are perhaps less likely to start their own businesses or to be successful if ever they should start a business (Driver et al., 2001: 4).

\subsection{Employment opportunities}

After completing their tertiary or secondary education, individuals usually embark on a search process for suitable employment opportunities. In this study, the respondents' own perceptions regarding future employment opportunities were probed into using the 'question'/statement: "I will have difficulty finding the kind of job I want when I have finished my full-time education”. 
Table 1.4 Perceptions about employment opportunities according to

\begin{tabular}{|l|c|c|c|c|c|c|c|}
\hline Gender & $\begin{array}{c}\mathbf{0 =} \\
\text { Strongly } \\
\text { disagree }\end{array}$ & $\begin{array}{c}\mathbf{1}= \\
\text { Disagree }\end{array}$ & $\begin{array}{c}\mathbf{2 =} \\
\text { Not sure }\end{array}$ & $\begin{array}{c}\mathbf{3}= \\
\text { Agree }\end{array}$ & $\begin{array}{c}\mathbf{4}= \\
\text { Strongly } \\
\text { agree }\end{array}$ & Total & $\begin{array}{c}\text { Mean of } \\
\text { opinions }\end{array}$ \\
\hline Female & 33 & 37 & 71 & 32 & 13 & 186 & 1,76 \\
& $51,6 \%$ & $61.7 \%$ & $62,8 \%$ & $40,5 \%$ & $46,4 \%$ & $54,1 \%$ & \\
\hline Male & 31 & 23 & 42 & 47 & 15 & 158 & 1,95 \\
& $48,4 \%$ & $38,3 \%$ & $37,2 \%$ & $59,5 \%$ & $53,6 \%$ & $45,9 \%$ & \\
\hline Total & 64 & 60 & 113 & 28 & 28 & 344 & 1,85 \\
& $100,0 \%$ & $100,0 \%$ & $100,0 \%$ & $100,0 \%$ & $100,0 \%$ & $100,0 \%$ & \\
\hline
\end{tabular}

About a third (124) of the respondents (36 per cent) disagreed or strongly disagreed that they would have problems finding the job they wanted, 32,8 per cent was unsure and 31,1 per cent agreed or strongly agreed, and therefore demonstrated positive job expectations. When respondents' responses to this question were analysed according to gender (Table 1.4), it is found that females (mean score $=1.76$ ) appear to be more apprehensive than males (mean score=1.95) about employment opportunities. Male respondents are perceived to be more positive about their future career opportunities than their female counterparts. This response is in line with literature reports that the unemployment rate is higher for young women (49,6 per cent) than young men (33 per cent) (Lehohla, 2001: 52). Thus, in accordance with the chi-square test $\left(x^{2}=11.56\right.$; d.f $\left.=4 ; p=0.02\right)$ the hypothesis of no relationship between gender and the respondents' perceptions about career opportunities could not be accepted with a confidence level of more than 95 per cent.

When the same responses were analysed according to population groups, there was no indication that the hypothesis of no significant association could be rejected with a 95 per cent confidence level $\left(x^{2}=30.5 ; \mathrm{d} . \mathrm{f}=8 ; \mathrm{p}=0.00\right)$. Blacks were found to be relatively more optimistic (mean score $=2.08$ ) than the other surveyed ethnic groups to obtain employment with ease after the completion of their full-time education.

Unemployment in South Africa is higher in the rural areas or among black youth than in other areas. The results of this survey, however, did not indicate that either of those two locational groups perceived themselves to find jobhunting less problematic than the other participants. The rural youth learners perceived that, on average (mean score $=2.02$ ), they might have more difficulty in finding a suitable employment after completion of their full-time education than their urban counterparts (mean score $=1.79$ ). About a third (35 per cent) of the respondents agreed that they might encounter problems in their job search 
exercise; of these the overriding majority was from a non-rural background. However, the chi-square test does not seem to indicate a significant association between locality and the respondents' perceptions of about career/ employment opportunities.

\subsection{Perceptions regarding respondents' future and enterprise}

Respondents were asked questions regarding their own knowledge, future plans, perceptions about business, and the economic potential of their neighbourhoods. Their responses are summarised in Table 1.5:

Table 1.5 Perceptions regarding respondents' future and enterprise

\begin{tabular}{|c|c|c|c|c|}
\hline Questions & Yes & Undecided & No & Total \\
\hline $\begin{array}{l}\text { Do you think people in your } \\
\text { neighbourhood have the } \\
\text { opportunity to make good money } \\
\text { legally from a small business? }\end{array}$ & $\begin{array}{c}246 \\
66,5 \%\end{array}$ & $\begin{array}{c}100 \\
27,0 \%\end{array}$ & $\begin{array}{c}24 \\
6,5 \%\end{array}$ & $\begin{array}{c}370 \\
100,0 \%\end{array}$ \\
\hline Are most business people honest? & $\begin{array}{c}31 \\
5,6 \% \\
\end{array}$ & $\begin{array}{c}318 \\
86,0 \%\end{array}$ & $\begin{array}{c}21 \\
8,4 \%\end{array}$ & $\begin{array}{c}370 \\
100,0 \%\end{array}$ \\
\hline $\begin{array}{l}\text { Thinking about what you want to } \\
\text { be doing in future, do you know } \\
\text { exactly what steps you are going to } \\
\text { take? }\end{array}$ & $\begin{array}{c}119 \\
32,2 \%\end{array}$ & $\begin{array}{c}199 \\
53,8 \%\end{array}$ & $\begin{array}{c}52 \\
14,1 \%\end{array}$ & $\begin{array}{c}370 \\
100,0 \%\end{array}$ \\
\hline $\begin{array}{l}\text { After high school graduation, do } \\
\text { you plan to continue your studies } \\
\text { ? }\end{array}$ & $\begin{array}{c}291 \\
78,7 \%\end{array}$ & $\begin{array}{c}59 \\
16,0 \%\end{array}$ & $\begin{array}{c}20 \\
5,4 \%\end{array}$ & $\begin{array}{c}370 \\
100,0 \%\end{array}$ \\
\hline $\begin{array}{l}\text { Would you like to have a business } \\
\text { of your own eventually? }\end{array}$ & $\begin{array}{c}242 \\
65,4 \% \\
\end{array}$ & $\begin{array}{c}71 \\
19,2 \% \\
\end{array}$ & $\begin{array}{c}57 \\
15,4 \% \\
\end{array}$ & $\begin{array}{c}370 \\
100,0 \% \\
\end{array}$ \\
\hline $\begin{array}{l}\text { Do you have a special talent that } \\
\text { you could use to earn a living? }\end{array}$ & $\begin{array}{c}269 \\
72,7 \%\end{array}$ & $\begin{array}{c}78 \\
21,1 \% \\
\end{array}$ & $\begin{array}{c}23 \\
6,2 \%\end{array}$ & $\begin{array}{c}370 \\
100,0 \%\end{array}$ \\
\hline $\begin{array}{l}\text { Do you know enough about } \\
\text { business to start your own business } \\
\text { and make a profit? }\end{array}$ & $\begin{array}{c}126 \\
34,1 \%\end{array}$ & $\begin{array}{c}108 \\
29,2 \%\end{array}$ & $\begin{array}{c}136 \\
36,8 \%\end{array}$ & $\begin{array}{c}370 \\
100,0 \%\end{array}$ \\
\hline
\end{tabular}

Table 1.5 shows that 66,5 per cent of the respondents believed that there existed the opportunity in their neighbourhood to run legal businesses profitably. The concern arises whether the response to this legal business opportunity question will differ according to neigbourhood, seeing that some of the local areas have less visible safety issues, for example gangsterism, than others and even need to close schools during high risk periods. The responses from the white and the coloured population groups were the most optimistic. When the relationship of 
the respondents' views of the opportunity to make legal profit in their communities was tested, the results showed that there was a significant relationship at 95 per cent level $\left(x^{2}=11.48\right.$; d.f $\left.=4 ; p=0.05\right)$. This was an indication that views regarding entrepreneurship opportunities differed from neighbourhood to neighbourhood. There were also significant differences regarding the male and female respondents' perceptions about legal business opportunities in their neighbourhoods $\left(x^{2}=6.04\right.$; d.f $\left.=2 ; p=0.04\right)$. Males were marginally more negative about the prospects.

The respondents had serious doubts about the honesty of business people and the results to this question do not reflect well on South Africa's business society. The majority (86 per cent) were not sure whether business people were honest, while a minority ( 8,4 per cent) believed that most business people were dishonest. There was a significant relationship between the population groups and the responses to this question on a 95 per cent confidence level, with the white respondents being more positive about the honesty of business people. This result confirms the claims of Driver et al. (2001: 4) that there were low levels of trust regarding business and personal relations in South Africa.

At this late stage in their school career only 32 per cent of the respondents had a clear idea about the steps they needed to take regarding their future. There was a significant difference between the various population groups regarding the clarity they had about the future; the black respondents being proportionately more positive in their report than the other group of learners. More non-rural students reported that they had no idea what steps they were going to take.

The majority of respondents (78 per cent) planned further study after completing their high school education. Again their study plans showed a strong relationship with their population groups, with 91,8 per cent of the black respondents, 85,9 per cent of the white respondents and 69,9 per cent of the coloured respondents planning further studies. O’Neill and Van den Berg (1991: 13) reported on an earlier survey in the same community where 83,3 per cent of the white respondents and 33,8 per cent of the coloured respondents had planned higher education. (No black respondents participated in the earlier survey.) Comparing the responses of the two surveys, it is evident that the white learners' responses were very similar to the previous results but the percentage of coloured learners that wanted to continue their studies doubled. This could be ascribed to higher aspirations in post-apartheid South Africa and the fact that there is now a wider range of study opportunities available, sometimes with higher accessibility to learners from disadvantaged areas than had been the case a decade ago. Not only did 92 per cent of the black respondents plan to study further, they had the highest percentage of respondents (38,8 per cent) of all the groups who indicated that they knew exactly which steps to take towards their future. More of the non-rural 
respondents (85,3 per cent) than the rural ones (58,7 per cent) reported that they planned to continue their studies. There was no significant gender association between the responses of the female and male students and their plans to further their studies.

About two thirds (65,4 per cent) of the respondents indicated that they would like to have their own businesses eventually. Kourilsky and Carlson (1997: 193) reported that 69 per cent of the American youth included in a Gallup Poll on entrepreneurial education indicated that they wanted to start their own businesses, including 80 per cent of the African Americans in the group. This study of entrepreneurship as a career option is somewhat similar to that of Black, Corbin and Warburton conducted in North West England in 2002. Using a "worldview approach" to career choice as a point of departure, Black et al. (2003: 8) found that "career aspirations are relatively stable and develop according to clear trajectories, shaped by experiences of young people in a range of contexts". However, they added that the "worldview" with regard to entrepreneurship is likely to change when students become equipped with the skills and knowledge which allow them to recognize the potential or market value of their creative ideas ( Black et al., 2003: 22).

In an earlier survey in South Africa 38,5 per cent of the White learners and 31,6 per cent of the coloured respondents in the same community expressed a positive desire to run their own businesses eventually, when they responded to the same question (O’Neill \& Van den Berg, 1991: 12). Although the results cannot be compared in a scientific way because the learners who attended schools during the second survey differed and were, for instance, a more culturally diverse group than was the case a decade ago, there seem to be strong indications of a move towards more young people intending to become business owners, among all population groups.

There was no significant difference between the responses on this question regarding business intention according to the locality of the respondents. However the responses of male and female participants to this question differed significantly on a 95 per cent confidence level. Where 76,4 per cent of the male students indicated that they wanted to start businesses, only 55,6 per cent of the female students gave the same response. These results point that gender differences showed a significant relationship with entrepreneurial intent, but not ethnic differences or rural/non-rural differences.

Almost 72,7 per cent of the respondents believed that they had talents that they could use to earn a living. This seems to reinforce the point that a large portion of the respondents might seriously consider entrepreneurship as a career option to the extent that they had already started to evaluate their own marketable skills 
and talents, and reported positively on the results. The responses of male and female to this question did not differ significantly. There was no significant difference between the responses of the rural and non-rural students either. Only 34 per cent of the respondents believed that they already knew enough about business to be able to start a profitable business. More of the non-rural, White group and male learners believed that they knew enough about business to be able to make a profit. Since white people, men and non-rural people are statistically more likely to start businesses, it is important to note that these groups were more confident regarding their business knowledge than the other learner groups. According to the GEM report "Individuals belief in their own ability to launch a new business is expected to have a powerful influence on their decision to do so" (Foxcroft et al., 2002: 21). When the relationship between the respondents' perceived business knowledge and the reported likelihood to start a business was examined, the hypothesis of no association could not be accepted with confidence level of more than 99 per cent $\left(\mathrm{x}^{2}=\right.$ 36.23 d.f $=4 ; \mathrm{p}=0.00$ ). There seem to be a strong relationship between perceived business knowledge and business intentions. The surveyed high school learners were relatively positive about themselves and their own futures, and extremely positive about the possibility of eventually owning their own enterprises.

\section{SELF-IMAGE}

The respondents answered twenty questions to indicate their respective positive self-image levels. The overall score of each learners is arrived at by adding the score of each question. The self-image scores of respondents (on a scale between 0 and 80 ) are summarised in Table 1.6.

Table 1.6 Summary of self-image scores of respondents

\begin{tabular}{|l|c|c|}
\hline \multicolumn{1}{|c|}{ Scores } & $\begin{array}{c}\text { No. of respondents } \\
\text { (frequency) }\end{array}$ & Percentage \\
\hline $0-20$ & 18 & 4,86 \\
\hline $21-30$ & 12 & 4,24 \\
\hline $31-40$ & 41 & 11,08 \\
\hline $41-50$ & 95 & 25,68 \\
\hline $51-60$ & 123 & 33,24 \\
\hline $61-70$ & 64 & 17,30 \\
\hline $71-80$ & 17 & 4,59 \\
\hline Total & 370 & 100,00 \\
\hline
\end{tabular}


"Self-image" is measured on a five-point scale by a number of questions (worded in negative and positive ways) with a theoretical zero-base. From Table 1.6 it is evident that the self-image scores of the respondents had a wide spread. A summary of the total scores of each respondent on this factor shows that the results varied between 16 and 80 . About a quarter of the respondents had a self image score of 41-50 and another third had a score of 51-60. Selfesteem is no indication of skill or aptitude, because it can be either realistic or unrealistic and can differ between various life areas (Baumeister et al., 1996: 533).

Driver et al. (2001: 40) reported that people were lacking confidence, initiative and creative thinking as a result of the formerly predominant authoritarian school system, especially during the apartheid years. They anticipated that white children would suffer less severely from this system and had more selfconfidence than other groups. Although Black and Coloured respondents were less positive about entrepreneurship in general (Figure 1), and the possibility of starting their own business (Table 1.2), there was no indication that the results of self-image (Table 1.6) differed significantly according to population groups. It may indicate that many members of the younger generation were not suffering from a lack of confidence or negative self-image in the post-apartheid South Africa any more.

The respondents from rural areas had on average lower self-image scores (4.28) than the urban learners (4.56). There was a significant variation in the selfimage score among the 8 surveyed schools, with the average score ranging between 4.09 and 5.36 units.

Learners with more positive and high levels of self-image might be more inclined to start a business and be successful at it than those with a low selfimage. However, in this study, self-image did not seem to be significantly related to the respondents' intentions to start businesses. This can be due to the fact that self-image is a complex concept. Persons with more positive selfimage can do well in any occupation, whereas those with a low self-image often find it difficult to adapt to the challenges of the changing wage employment and often escape from this deficiency through starting a small business venture. This relationship between schools and self-image emphasises the important formative role that schools can play in the life of the learners by instilling relevant academic, business and positive life-long skills. 


\section{DISCUSSION}

A daunting challenge facing South Africa is how to create jobs for its increasing number of jobless individuals, apparently living under conditions of rising poverty. High economic growth rates, underpinned by the labour-hiring and capital investment actions of entrepreneurs, are critical for job creation and poverty alleviation. But in South Africa there is a huge shortage of high level entrepreneurs and many obstacles to entrepreneurship, such as access to financing, corruption, high crime rates and prohibitive labour legislation. The formal sector has been shedding labour in recent years, while its labour absorption capacity has been steadily declining in the past couple of decades. Considerable focus should, therefore, be placed on the youth and school learners as they constitute, as a human capital group, the future leaders and jobcreators of the country. As the annual number of matriculants and unemployed people increase in South Africa there would be an increasing number of individuals who would want to work for themselves, in both the formal and informal sectors. As this study indicates, almost three-quarters of the surveyed grade 12 learners believed that they have acquired the basic talents that could be harnessed into a business venture. Schools should become active institutional role players in promoting commercial subjects, business skills and entrepreneurship as a career choice, as well as in building the self-image and positive "I can" attitudes among young learners.

The self-image of the surveyed youth learners was generally positive. While self-image is found not to differ significantly among the population groups, the location of schools could partially account for a difference in the self-image among the learners. The rural group had a significantly lower self-image than their metropolitan counterpart.

Given the current labour market scenarios in South Africa, about two thirds of the respondents felt that they might experience difficulty to find the kind of employment they wanted (only a third did not foresee a problem in that regard). Almost 67 per cent of the respondents believed that there were profitable business opportunities in their neighbourhoods. The perceived social norms regarding entrepreneurship proved to be fairly positive and respondents were relatively positive about the personal option of entrepreneurship as a career option, although there were indications that realities might for some groups lead to an inner doubt whether entrepreneurship would really be able to fulfill its promises.

Although females did not differ significantly regarding their perceptions about entrepreneurial social norms and personal entrepreneurship, they were marginally more negative about the availability of job opportunities, in their 
intentions to start businesses, and their perceived business knowledge than male learners. It seems that this group has in some ways been able to overcome stereotypes regarding women in business, but in practice not been able to fully do so yet.

Compared to previous research results there was a marked increase in the proportion of learners who intended to start their own businesses (this survey reported a proportion double the size of the report a decade ago), as well as in the proportion of respondents from the coloured population group who intended to continue studies after grade 12 . The differences indicate more positive attitudes regarding entrepreneurship and higher aspirations even among the grade 12 learners.

The absence of trust in business people was evident both from the literature and the survey. The importance of this issue for the well-being of the economy is often not recognised in the South African society. Business ethics should be part of entrepreneurship and business skills training in order to stimulate prospective business people to start thinking about ethical questions that they will have to answer in their conduct of businesses. The youth business initiatives can contribute favorably to unemployment if the failure rate among small businesses is decreased and perceptions associated with such failures are changed in society. Special attention needs to be paid to augmenting the rates of entrepreneurship among the youth if South Africa is to reach developing country norms (Orford et al., 2003: 51).

\section{CONCLUSION}

Entrepreneurship is critical to combating unemployment and poverty in South Africa. The country does not suffer from a lack of creative spirit, but rather from a lack of business education and entrepreneurial skills in an enabling environment that can empower individuals to further themselves through taking the entrepreneurship route. Certain sectors of the previously disadvantaged population were deprived of opportunities and quality education in the apartheid era. However schools have become integrated in the new dispensation and opportunities are now open to all.

From the current research it is encouraging that entrepreneurial perceptions and opportunities have already changed considerably over the last decade. The surveyed youth learners from both rural and urban school backgrounds and from the white, black and coloured population groups seem to have a positive disposition towards self-employment and small business entrepreneurship as an eventual career, although differences exist in terms of self-image, business 
skills, location and gender. With relevant education and training as well as adequate entrepreneurial development support, youth entrepreneurship can be further empowered. Perceptions regarding failure, which could be part of a learning curve, should be specifically targeted to educate society not only to reward success, but also emulate role models in business who learn from mistakes and spring back into actions. Admittedly, certain entrepreneurial skills or aspects of entrepreneurship cannot be taught. However, encouraging entrepreneurial activities and teaching entrepreneurial skills or attitudes to school children is certainly a possible means of inculcating self-confidence, a need for achievement and employability prospects in South Africans and other learners from a young age.

\section{ENDNOTE}

The authors would like to thank the anonymous referees for their helpful comments on this paper.

\section{REFERENCES}

1 BAUMEISTER, R.F., SMART, L. \& BODEN, J.M. (1996) "Relation of threatened egotism to violence and aggression: The dark side of high selfesteem”, Psychological Review, 103(1): 5-33.

2 BHORAT, \& LEIBBRANDT, M. (1998) "Poverty amongst the selfemployed”, Studies in Economics and Econometrics, 22(3): 25-41.

3 BLACK, L., CORBIN, B. \& WARBURTON, T. (2003) "The contribution of "worldview" to pupils' attitudes on enterprise, entrepreneurship and entrepreneurial learning”, WPO3/05 Working Paper Series (On line) Manchester Metropolitan University.

$4 \quad$ BURCH, J.G. (1986): Entrepreneurship, Wiley: New York.

5 CAMPBELL, D.T. \& RUSSO, M.J. (2001) Social Measurement, Thousand Oaks: Sage.

6 DEVELOPMENT BANK OF SOUTHERN AFRICA (1998) Development Report 1998: Infrastructure a foundation for development, Midland.

7 DRIVER, A., WOOD, E., SEGAL, N. \& HERRINGTON, M. (2001) Global Entrepreneurship Monitor: 2001 South African Executive Report, INCE: Cape Town.

8 FERRIS, M-A. (2003) "Seek informal job skills matrics told", Cape Argus, 10 January: 6.

9 FOXCROFT, M.L., WOOD, E., KEW, J., HERRINGTON, M. \& SEGAL, N. (2002) Global Entrepreneurship Monitor: South African 
Executive Report 2002, The Graduate School of Business: University of Cape Town.

10 HARRISON, R.T., HART, M \& DONNELLY, M. (1989) "Attitudes to enterprise: Interim progress report”, Unpublished report.

11 KAPLAN. J (2003) Patterns of Entrepreneurship, John Wiley: New Jersey.

12 KOURILSKY, M.L. \& CARLSON, S.R. (1997) "Entrepreneurship education for youth: A curricular perspective" in Sexton, D.L. and Smilor, R.W. (eds.) Entrepreneurship 2000, Upstart: Chicago.

13 LEHOHLA, P. (2002) Stats in Brief 2002, Statistics South Africa: Pretoria.

14 LEHOHLA, P.L. (2001) "Employment among the youth in South Africa", Available: http://www.gov.za/reports/2001/youth3.pdf on 25/01/2002.

15 MAHADEA, D (1994) "Achievement motivation and small business success in Transkei”, Development Southern Africa, 11(1): 91-98.

16 MAHADEA, D (2003) "Employment and growth in South Africa: Hope or despair?” South African Journal of Economics, 171(1): 21-48.

17 MAY, J., WOOLARD, I. \& KLASEN, S. (2000) "The nature and measurement of poverty and inequality”, in May, J. (ed.) Poverty And Inequality In South Africa: Meeting The Challenge, David Phillip: Cape Town.

18 O’NEILL, R.C. \& VAN DEN BERG, J.M.M. (1991) “Attitudes to enterprise", Unpublished paper read at the National Marketing Educators Conference, Stellenbosch.

19 ORFORD, J., WOOD, E., FISCHER, C. HERRINGTON, M. \& SEGAL, N. (2003) Global Entrepreneurship Monitor: South African Executive Report 2003, UCT Graduate School of Business: Cape Town.

20 REYNOLDS, P.D., HAY, M. \& CAMP, S.M. (1999) Global Entrepreneurship Monitor: 1999 Executive Report.

21 SARB (2004) South African Reserve Bank Quarterly Bulletin, No. 231, Pretoria. 